\title{
P̈̈̈KKIRJOITUS
}

\section{YHTEISKUNTA VIESTII NÄKÖALATTOMUUDESTA}

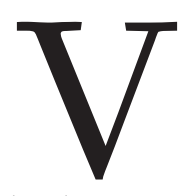

UONNA 2008 ALKANEEN globaalin finanssikriisin myötä epävarmuus on lisääntynyt yhteiskunnassa. Moni Euroopan maa on ajautunut konkurssin partaalle. Talouskasvu on hiipunut tai kääntynyt jopa laskuun. Suomessa valtiolliset päätöksentekijät ovat käyneet voimalla julkisten palvelujen kimppuun. Leikkauksia perustellaan sillä, että sosiaalietuudet ovat Suomessa liian anteliaita ja palvelutaso turhan korkea. Maan hallitus ja elinkeinoelämä ovat löytäneet toisensa kamppailussa yhteistä vihollista vastaan: ammattiyhdistysliikkeen vaikutusvaltaa halutaan murentaa ja palkansaajien palkkasummaa pienentää. Talouskriisin ja leikkausten vuoksi kansalaisten ostovoima vähenee ja työttömyys jatkaa kasvuaan.

Dramaattisin vaikutus talouskriisillä ja julkisen talouden leikkauksilla on muutenkin toimeentuloongelmien kanssa ponnisteleviin kansalaisiin. Vakinaisessa työssä olevia hyvätuloisia julkisten palvelujen leikkaukset ja palkanalennukset nipistävät, mutta eivät aja ahdinkoon. Avun varaan joutuvien määrä tulee kuitenkin lähivuosina kasvamaan. Erityisen haavoittuvassa asemassa ovat työmarkkinoille siirtyvät nuoret aikuiset.
YKSI 1990-LUVUN TALOUSLAMAN opetuksista on ollut se, että niin irtisanottujen kuin vasta koulutuksesta valmistuneiden nuorten kiinnittymisellä työmarkkinoille on pitkäkestoisia seurauksia. Pitkittyessään työn puutteesta juontuvat työllistymisvaikeudet heijastuvat koko myöhempään työuraan. Arja Jolkkosen ja Pertti Koistisen tutkimusryhmineen tekemä seurantatutkimus Kohtalokkaat olosuhteet ja yksilölliset tekijät todentaa, miten suhdanne- ja yksilölliset tekijät vaikuttavat työpaikkansa menettäneiden työllistymiseen sekä työurien jatkumiseen ja päättymiseen. Uudelleen työllistyminen eriytyy talouden suhdanteiden mukaan myös pitkällä aikavälillä. Huonossa taloussuhdanteessa työnsä menettäneet työllistyvät heikosti uudelleen.

Tutkimuksen mukaan vuonna 1992 työpaikkansa menettäneiden työllisyyden taso jäi huomattavasti alemmalle tasolle kuin muina vertailuajankohtina (1997 ja 2003) työpaikkansa menettäneiden työllisyys. Pitkäaikaisesti heikentyneen työllisyyden uralle joutuneiden osuus oli lamavuonna 1992 työttömäksi joutuneiden joukossa huomattavasti suurempi kuin myöhempinä vertailuvuosina työttömäksi joutuneilla.

Vanhimmat työntekijät siirtyivät pois työmarkkinoilta eläkkeelle tai työttömyyseläkkeelle. Työmark- 


\section{TALOUDEN}

TERVEHDYTT ̈̈MINEN

VAATII SUUREN JOUKON

IHMISUHREJA.

kinoille kiinnittyminen oli vaikeaa myös nuoremmille ja hyvin koulutetuille. Vajaatyöllisyys oli yleistä ja toistuvaa.

NE KYMMENET TUHANNET TYÖNTEKIJÄT, jotka joutuvat lähivuosina uhrautumaan talouden tervehdyttämisen nimissä, kärsivät pitkäaikaisista seurauksista. Hiljattain ilmestynyt nuorisobarometri Ihmisarvoinen nuoruus tarkastelee muun muassa nuorten työelämään ja työmarkkinoihin liittyviä odotuksia ja näköaloja. Päällimmäinen havainto on se, että nuoret ovat aiempaa enemmän huolissaan tulevaisuudesta. Jopa kolme neljäsosaa nuorista uskoo, että pysyvästi työelämän ulkopuolelle jäävien märä kasvaa tulevaisuudessa. Syrjäytymisen lisääntymiseen uskovien osuus on huomattavasti kasvanut kuudessa vuodessa.

Nuoret ovat huolissaan, paitsi työelämän muutossuunnasta yleensä, myös omasta tulevaisuudestaan työmarkkinoilla. Joka toinen nuori oli vuonna 2013 huolissaan siitä, riittääkö heille tulevaisuudessa töitä. Osuus on kasvanut kymmenellä prosenttiyksiköllä muutamassa vuodessa. Kaiken kaikkiaan nuorten optimistinen suhtautuminen omaan tulevaisuuteensa on vähentynyt vuosina 2008-2014. Työttömien nuorten optimistisuus on vähentynyt huomattavan paljon.

Viime aikoina mediassa esillä olleet koulutusleikkaukset ovat ehkä heijastuneet myös nuorten käsityksiin Suomesta maana, jossa on aiempaa vaikeampaa luoda itselleen hyvän elämän edellytyksiä. Nuoret suhtautuvat aiempaa pessimistisemmin tulevaisuudennäkymiin Suomessa ja globaalisti. Nuorisobarometrin valossa tulevaisuuteen suhtautumisen ja elämään tyytyväisyyden välinen yhteys on jotakuinkin kiistaton. Elämäänsä erittäin tyytyväiset suhtautuvat optimistisimmin omaan tulevaisuuteensa, melko tyytyväiset hieman vähemmän optimistisesti ja vähiten tyytyväiset kaikkien pessimistisimmin. Tyytymättömyys ja näköalattomuus ovat erittäin huono yhdistelmä itsenäistä elämää aloittelevalle kansalaiselle.

Nuorten epävarmuus erityisesti työn saamisesta on viime vuosina lisääntynyt merkittävästi. Huonojen työllisyysnäkymien vuoksi koko elämänusko joutuu koetukselle. Näköalaton tyytymättömyys voi olla ylisukupolvista. Lapsuuden perheen kokemukset saattavat vaikuttaa siihen, millaisina omat tulevaisuuden mahdollisuudet näyttäytyvät.

TALOUDEN JA TYÖTTÖMYYDEN ENNUSTEET viestivät työmarkkinoille siirtyville ikäryhmille näköalattomuutta. Eikä tulevaisuuden tekemisestä vastuussa oleva maan hallituskaan lupaa yhtään valoisampaa tulevaisuutta. Osa väestöstä joutuu tinkimään etuuksistaan ja tyytymään matalampaan elintasoon ja heikkenevään hyvinvointiin.

Eikö 20 vuodessa ole opittu mitään? Jo 1990-luvulla nähtiin, miten talouden tervehdyttämiseen tähtävät toimenpiteet vaativat suuren joukon ihmisuhreja. Leikkauksista seuraa aina ihmisuhreja. Pitääkö lisääntyvältä inhimilliseltä kärsimykseltä vain ummistaa silmät?

Heikki Silvennoinen 